\title{
Definition of Mysticism (Erfan) and Its Relationship with Healing as Approached by Halqeh Mysticism
}

\author{
Mohammad Ali Taheri
}

\begin{abstract}
The human being's mission is to seek Kamal (spiritual completeness), and illness is one of the obstacles that make it difficult. A patient is so engaged in his illness and its related issues that he thinks less about God and divine ambitions, whereas in health, the individual enjoys a better state in which to deliberate on God and self-awareness. Mysticism is in itself effective for healing. At times, the therapeutic intervention is quantitative and involves physicians, medicine, check-ups, and the like, and at times it is qualitative with no check-ups or medication. For example, when we pray for God to heal someone, we are moving towards their treatment, and if our prayer is granted without quantitative intervention, we have been engaged in their treatment. This intervention is not quantitative, and although the process's effect may be scientifically studied and observed, it is considered a qualitative intervention that is extremely effectual for achieving self-awareness. In a treatment like Faradarmani, an Iranian complementary and alternative medicine founded by Mohammad Ali Taheri, the individual becomes pragmatically familiar with Interuniversal Consciousness, and this experience is a turning-point that moves him towards the source of this consciousness. Thus, Faradarmani can mark the beginning of mysticism.
\end{abstract}

Index Terms-Faradarmani, halqeh mysticism, healing, inspiration, interuniversal consciousness.

\section{INTRODUCTION (GENERAL DEFINITION OF MYSTICISM OR ERFAN)}

The human being is always faced with two steps: the step of wisdom and the step of Love (Eshq). The step of Love is the world of ecstasy and enthusiasm, wonder and surprise, attraction and fascination, sacrifice and love, and so on. It is the framework and realm called the 'Tool-less (Free of Tools) World.' The practical part of Halqeh mysticism takes place on the step of Love and uses no tools [technique, method and skill, advice, counsel and reasoning, endeavor and effort, and so on]. It is on this step that awareness and illumination can be achieved. The steps of Love and wisdom are correlated [1]. Erfan (mysticism) means being present on the step of Love (Eshq), reaching illumination, enlightenment, and clarity of vision about the universe. Such results definitely cannot be attained through the world of wisdom (logic, science, and knowledge). As a general view and in brief, the world of Erfan has the following characteristics and definitions:

1) Since the world of Erfan is the world of Love (Eshq), there is no use of technique, method and skill, advice, counsel and reasoning, endeavor and effort, and so on;

Manuscript received April 17, 2013; revised June 26, 2013.

Mohammad Ali Taheri is with the Taman Universiti Johor, Malaysia (e-mail: mataheri2011@gmail.com). thus it is a world free of tools, either main or intermediary.

2) Erfan lays the ground-work for the unity of parts, and also communication between constituent and the 'whole'. As there are always things within the 'whole' of which the part is not aware, and by approaching the whole, such [awareness-giving] messages can be received. For instance, one single cell is void of desire and wish, but the unity of hundred trillions of cells make up the whole, which has desires and wishes, and follows certain purposes, whereas a single cell does not even know the meaning of desire.

3) Erfan is the perception of Kamal $^{1}$. It studies the awareness (es) that are transferable to the next life ${ }^{2}$.

4) Since Erfan is the world of Love, it is not a place for monopoly or exclusivity. It encompasses all human beings, and regards everyone as included in Divine Love.

5) As Love requires action and not mere spoken or written words and so on, Erfan is the world of action and [its outcomes] must be tangible.

6) Erfan is a movement from the appearance to essence.

\section{MYSTICISM AND ESSENCE-VIEWING}

Erfan changes the appearance-viewing vision into an essence-viewing vision. [This is a movement from seeing appearance to seeing substance. Seeing substance is 'discovering the final Kamal of things in the universe.' When one achieves this Godly vision, one understands the grandeur of creation in every single constituent of the universe. Having substance-seeing vision reveals three aspects of everything: appearance, substance, and essence. (For details please refer to 'Human Insight', by M.A. Taheri)]. All human beings are born with an appearance-viewing eye, and the majority, even in their worship, count on prayer's outer shell. However, the world of mysticism is a world of achieving deeper insight. Erfan opens up the eye of the heart to witnessing God, so that His image is seen in everything.

\section{I look everywhere, mountain, plain and field,}

\footnotetext{
${ }^{1}$ The term Kamal literally means completeness and refers to the human's spiritual growth toward completion (perfection). It includes self-realization and self-awareness, meaning clarity of vision about the universe, where we have come from and for what purpose, and where we are heading. It is attaining possessions, which are transportable to the next life, and includes the perceptions such as unity, the magnificence of the Beloved, and His presence, all of which are discussed in the book "Human from Another Outlook", M.A. Taheri.

${ }^{2}$ According to Halqeh mysticism we are travelling toward God through a pathway that 'returns us back to him.' It is an inherent movement toward Kamal which is composed of various lives. Each of these stages ends with death, and the next life (stage) begins. For instance, after dying in this stage [life on earth], the stage of "space-lessness" begins, and, after that the stage of "timelessness and space-lessness" comes (please refer to 'Human Insight', by M.A. Taheri).
} 


\section{It all symbolizes You}

-Baba Taher (Iranian poet)

Thus, in the course of Erfan, the human being develops an essence-viewing eye that rescues him from a polytheistic view and draws all his attention to God.

Human beings can reach a level in which nothing is seen except God. Look how high humanity's eminence can be. -Sa'adi (Iranian poet)

Certainly, essence-viewing does not mean mind-reading, personality-reading, and the like because on the basis of God's 'covering the faults' [honoring people's right of privacy and confidentiality], these abilities that intrude into the private boundary of others cannot be divine.

\section{MYSTICISM AND THE QUALITY OF LIFE}

All the human being's acts or thoughts possess two dimensions: quantitative and qualitative. These two dimensions have always been inseparable and will remain so. For example, consider the prayer. A person can say a prayer or he can be in constant prayer [the latter meaning that $\mathrm{s} /$ he can perceive the magnificence of the Beloved ${ }^{3}$, and other perceptions and awareness about God and the universe]. These two comprise utterly different qualities, whilst being the same quantitatively. That is, in both, the prayers, ablution, required clothing, place, exist, and the physical movements of the prayer are made towards a certain direction; nevertheless, an absolutely different quality governs each. Qualitative improvement of acts is attained through the step of Love, and is an outcome of Erfan. For this reason, Erfan can be regarded as a type of qualitative enhancement.

In addition, as mentioned, the human being views the universe from two perspectives: quantitatively and qualitatively. Between these two, mysticism is also considered the qualitative perspective on the universe [2]. Quantitative approach is the perspective of wisdom that analyses all subjects from a quantitative viewpoint; whereas, the qualitative approach originates from the heart, and discovers the quality of the universe, and evaluates the quality of human demeanor and behaviors.

\section{Mysticism AND the ART OF BeCOMING SHOCKPROOF}

Life is like a raging ocean, and at any second we can expect tidal waves to strike. Anyone who plans to cross the ocean in a fragile vessel, will certainly be smashed once

\footnotetext{
${ }^{3}$ In the realm of Eshq, there is a principle that serves as a valuable yardstick for recognition of being in love: "The one in love finds the beauty and magnificence of the beloved faultless." The LeyIi and Majnoon story (an Iranian love poem by Nezami) teaches this lesson clearly to man. In the story, their love became a word of mouth and everyone assumed how beautiful Leyli must have been to have made Majnoon so crazy for her love, to such a level that he wandered about in the plains and deserts. Therefore, everybody was curious to see her, and finally the king summoned LeyIi to his palace. He wanted to see her, face to face, to see the beauty that had created such a great love. However, when the king finally met Leyli he was amazed to find her quite an ordinary girl. Therefore, he told her, "Then it is you that have caused Majnoon to [madly] wander about in the deserts, but you are not prettier than the others?!" In response, Leyli unveiled the great truth: "It is the way Majnoon perceives me that has indeed caused such a passionate love and it his loving eyes that cannot see my flaws". Someone who has such eyes as Majnoon's can pass through both worlds easily as he cannot see any fault in
} them. struck by a few of these waves, and his boat will be shattered and its pieces scattered. With Erfan, man can change the vessel of his being into an oceangoing ship, so he can sail across life's ocean more securely. That is, Erfan is the art of becoming shock-proof, and by increasing one's inner capacity, controlling negative modes and emotions, and the like, it protects the human being in life's confrontations with undesirable changes. A mystic on the path towards his goal is not obstructed by each blow or shock, and, contrary to normal people, he is hardy and shock-proof [3].

If we drop a coin into a bowl of water, instantly, upon looking into the bowl, we see the coin. However, if we drop the same coin into a pond, it will be a little harder to see, and if dropped into a deep pool, seeing it becomes even harder. If the coin is dropped into a large lake, there is small hope of ever finding it, [the hope of finding our 'coin' diminishes proportionately to the growing size of the body of water].

The impact of unpleasantness on the individuals' existence can be compared to the coin and their capacity to the bowl, lake, and the like. Erfan trains people with high inner capacities, who are able to bury all unpleasantness, careless and nonsense speech, sneers, insults, affronts and disrespects forever in a manner that makes them hardly recognizable in their being.

\section{MYSTICISM AND INSPIRATION}

Mysticism is attaining awareness of Kamal. Mysticism provides the total awareness that is transferable to our next life [after his physical lifetime on Earth]. Travelling through the pathway of Kamal, which in Erfan is called exploration and transformation, depends on how much we know about the path. This saves us time by helping us to prepare all the necessary things. Therefore, it is necessary to have some information about the next lives, such as that our next (immediate) life continues in the space-less dimension. There, we lose the dimension of space [place, distance,...] and can be present everywhere at the same time, with only the dimension of time ruling us. Now, if we identify and classify the belongings of an individual, we can decide which category has use in the next life.

By studying and categorizing the human being's possessions, we can determine which are useful in the next life. Earthly possessions include all knowledge, powers, abilities, expertise and all the information required for day-to-day life, without which life would be difficult, but are not useful in our next lives. For instance, the science of economics, [the skills in] accountancy, engineering a car or a computer or a building or an airplane, sport skills, and so on, have no use in the next life, and cannot be transferred. They are beneficial and effective in the next life only if they lead the individual to the understanding and perception of Kamal; otherwise, they are considered futile. Therefore, none of the powers and capabilities gained through sport, exercise, and practice, such as weight lifting, skiing, jumping, the skills of typing, driving, or hairdressing is itself of any use in the next life. It is only the results gained from such activities that can help us in achieving our main goal of living (Kamal). For example, we engage in sport and exercise to be fit, to stay healthy and to not become ill, so that we can explore the 
framework of Kamal more easily and thoroughly. We gain certain professional skills and qualifications to be able to earn a living, and in turn facilitate our search for answers to questions about our Kamal such as 'who we are?' and 'what is the purpose of our creation?'

The other category of human's possession that we call 'metaphysical abilities' has two subdivisions:

- Powers such as mind-reading, telling the future, reading others' personalities and similar abilities that have absolutely no use in the next life despite the several years of life the individual wastes acquiring them. for example, if someone can teleport himself in this life, that power would be useless in the next life, since there is no space dimension in the next life, and instantaneous teleportation is possible for everyone. The same applies to foretelling or reading others' minds and the like.

- Knowledge of Kamal, which includes all the awareness that we need on the pathway of Kamal. As mentioned, this division is the only part of human possessions transferrable to the next life, and includes perceptions such as Ana-al-Haqq ${ }^{4}$, magnificence of the Beloved, Unity of the universe, and purposefulness of creation and so on.

In short, all human possessions fall into two general groups, "Kamal" and "power," and only the knowledge of Kamal is worth pursuing, and power in all its forms is frail and wastes the human lifetime. Power sometimes even appears in the form of a Divine gift, only to be at the service of the Negative Network ${ }^{5}$. Molana Rumi ${ }^{6}$ likens power to candy and considers it the food of children. He suggests avoiding eating it and waiting until the main course that contains the perception of Kamal comes along:

Patience, is in the hands of the insightful,

Candy, only the desire of children's feast.

Those who are patient go beyond and above the world.

Those who eat candy only sink distant from the goal. -Molana Rumi

All metaphysical awareness that the human being receives belong to either the "Positive Network" or the "Negative Network." The information from the Positive Network guides man towards Kamal and facilitates his movement from multiplicity ${ }^{7}$ towards unity ${ }^{8}$. Amongst its outcomes is

\footnotetext{
${ }^{4}$ Perception of "Ana-al-Haqq (I am the Truth (God)" and that He is in the center of our existence (perception of 'The House Of God').

${ }^{5}$ The negative network provides all the information and awareness that can distract and distance one from the path toward Kamal [Kamal-thwarting network].Without the existence of such a hindering force, journey toward Kamal would fail to provide the necessary values, because there would be no need to exert effort or strategies to reach Kamal. And so, the human being is constantly dealing with two forces and attractions. (For details please refer to 'Human from Another Outlook', by M.A. Taheri)

${ }^{6}$ A 13th-century Persian Muslim poet, jurist, theologian, and Sufi mystic.

${ }^{7}$ The realm of Multiplicity is applied to a world in which human beings are separated from each other to such an extent that each individual's world is merely limited to himself; where one cannot recognize [anyone] outside the self. One is self-centered and cares only for himself, and all his attention is constantly focused on protecting his private interests and material earthly life. This trend leads to self-conflicts, and the individual's contradictions reach their maximum level. In the realm of multiplicity, no two people can ever tolerate each other.

${ }^{8}$ The world of Unity is a world that is perceptual (needs to be perceived) in which an individual perceives the Unified Body of existence, and the universe with all its constituents are perceived as divine manifestations. The purpose of Halqeh mysticism is to help people reach Kamal and
}

attaining inner joy, peace, and so on. In contrast, information that facilitates showing off, obtaining personal gains, gaining dominance and influence over others, mind-reading, or information that contradicts God's justice, fault-veiling, denies responsibility, violates a person's freedom of choice and personal privacy, and causes multiplicity, all come from the Negative Network. The Positive Network never provides anyone with such information.

Amongst the outcomes of knowingly or unknowingly using the information received from the Negative Network are feeling anxious and restless, depression and disappointment, sorrow and grief, and loneliness. All the information that induces fear and terror, worrying and stress, disappointment and hopelessness, sorrow and grief, depression and the like, received when awake or asleep, are definitely from the Negative Network.

\section{1) Awareness coming from the positive network}

- The philosophy of Creation

- The purpose of Being, and how to reach Kamal

- The way to resolve conflicts and reach unity [with God, universe, one's self and others]

- The way to attain the perception of Kamal

- Perception of the unity of the universe [Unified Body]

- Perception of Ana-al-Haqq

- Perception of the Beloved's magnificence

- Perception of the purposefulness of His creation

- Perception of His presence ${ }^{9}$

2) Awareness coming from the negative network

Awareness regarding gaining power and superiority over other; Discovering others' faults and reading their personality; Encouragement to judge others; Awareness that positions the individual into the Negative Phase ${ }^{10}$; Pushing the human beings towards multiplicity; Awareness for developing powers such as mind-reading, telling the future, trespassing on others (bewitching); Awareness which empower selfishness and self-centeredness; Awareness that is in violation of justice; Awareness that are in violation of free will; and the like

\section{RELATIONSHIP BETWEEN MYSTICISM AND PEACE IN LIFE}

Mysticism applies to all affairs of life, because every part of life needs perfection-seeking and qualitative promotion. Mysticism is acquainted with all aspects and is not applied

transcendence, a movement from the world of Multiplicity to the world of Unity. All efforts are for bringing people closer to each other, and any factors that separate people and create division among them is avoided.

${ }^{9}$ The ardor and yearning of His lovers for His union, brings about incomprehensible exaltation. We are travelling toward God through a path that returns us to Him. In this phase of life, [the experience of] joining Him is indeed the perception of His "Presence", higher than which a human cannot experience. Therefore, while we are within our physical body, the maximum level of union with God is reaching the perception of His presence.

${ }^{10}$ Psychological Body (psyche) is composed of two positive and negative sections. The negative section discovers negative feelings such as anger, revenge, hatred, greed, jealousy and displays them. As a result of negative feelings, on the one hand, the brain carries out the relevant response on the body and produces toxins, on the other, the negative section of our psyche produces negative emissions which we expose others and ourselves to; in this state we are idiomatically in the "Negative Phase" (For details please refer to 'Human from Another Outlook', by M.A. Taheri). 
merely to reach peace or pleasant psychological and emotional state. Peace is effective in finding answers to questions related to ontology and anthropology, but this is not the target because if the human being sets himself any goal other than Kamal, he will be harmed.

Accomplishing the mission of 'being a worshiper' calls for facilities towards Kamal. For instance, with inner stability or peace, we can better perceive the answers to issues such as 'our place and mission in the world' and 'what we need to achieve as a human being.' Finding the correct answers to these questions is self-awareness, and self-awareness is one of humankind's duties. In this regard, there are additional (overtime) actions [4] that are not essentially duties but prepare the grounds to become nearer to God. For example, control of one's mind [5] and reaching peace are not duties in themselves, but they are significant means for better accomplishing the goal of self-awareness, and in turn theism.

On the path to the peak of Kamal, peace is a station which we must pass, because peace is not the end but the means [4] for improving self-awareness and attaining a deeper understanding of the universe. The objective of our existence in the universe is not to reach peace. Peace is an essential, yet insufficient, state. It is necessary for the human being to reach an existential static. This is achieved through intimacy with God. By coming close to Him, the heart becomes peaceful. "Truly, the presence of God calms hearts." Peace refers to existential stasis. Now, suppose a person's existence is static, what will he do afterwards? If people with tottering, anxious, and worried existence find constancy and stability, how will they benefit from it? The human being needs to know where he comes from, why he is here and where will he go. These questions are linked to Kamal. Peace, in itself, does not answer these questions; however, by reaching tranquility and stability, we can better pursue the answers to these questions.

\section{God's Mercy in Reaching PeACE}

Mystical facilities are the outcome of man's own motivation and decision, and he himself chooses the way to approach them. Nevertheless, he faces two options: rely on himself, or rely on God. In other words, the human being can achieve inner transformation in two ways. One is through Self-centeredness and the other, through God-centeredness. Self-centeredness means reliance on personal abilities which are obtained through his own efforts. In contrast, in God-centeredness, Divine Communal Mercy is applied. Generally, all human beings regardless of their race, nationality, gender, age, education and knowledge, individual talents and capabilities, religion and faith, sinfulness or innocence, and purity or impurity and so on, can benefit from the Divine Communal Mercy. Divine Grace flows in different forms through various Halqehes ${ }^{11}$ that can be practically utilized.

\footnotetext{
${ }^{11}$ Halqeh mysticism (Erfan-e Halqeh) is based on the connection or Ettesal to the several circles or Halqehes of the Interuniversal Consciousness and the entire path of exploration and transformation is by means of connection to these Halqehes. Each Halqeh of Interuniversal Consciousness provides us a special facility. (Human from NAothe Outlook, M.A. Taheri)
}

Nobody reaches anywhere by his own ability, Only You can put him forth the light of mercy-Sa'adi

A mysticism that is founded on the connection with God is not self-centered and does not create inner transformation in anyone through practice and exercise; on the contrary, it is only based on God's mercy. Relationship between Peace and Nearness to God

The beginning and the end of peace cannot be defined as it is a qualitative subject. One of the characteristics of a transcendent person is being peaceful. However, the closer we become to God and the divine nearness occurs, or the more we become self-aware leading to God-awareness, the more we reach a higher existential stasis and stability, thus our being is protected from instability and anxiety.

\section{RATIO BETWEEN MYSTICISM AND HEALING}

The human being's mission is to seek Kamal, and illness is one of the obstacles that make it difficult. A patient is so engaged in his illness and its related issues that he thinks less about God and divine ambitions, whereas in health, the individual enjoys a better state in which to deliberate on God and self-awareness. In this regard, in mysticism, which is the study of Kamal and self-awareness, illness is considered a type of barrier. Of course, this does not mean that none of the sick people can be on the path of Kamal; however, following that path cannot be expected of some patients such as the depressed, schizophrenic, or other patients and it is often relatively less expected from individuals with any other type of disease, compared to healthy individuals.

In qualitative enhancement, respectively, the health of mind (Zehn), psyche and body are important. For example, when the mind is sad, it cannot give much attention to Kamal. Only by pushing aside the barriers, can we seek answers to 'Who am I,' 'Where have I come from,' and 'Where will I go.' Therefore, the state of health that has a close relation with peacefulness is a mystical necessity that facilitates progress towards Kamal.

In a complementary manner, mysticism is in itself effective for healing. At times, the therapeutic intervention is quantitative and involves physicians, medicine, check-ups, drugs, and the like, and at times it is qualitative with no check-ups or medication. For instance, when we pray for God to heal someone, we are moving towards their treatment, and if our prayer is granted without a quantitative intervention, we have been engaged in their treatment. Praying is a therapy with qualitative intervention, as is inviting a patient to become connected to God. This intervention is not quantitative, and although the process's effect may be scientifically studied and observed, it is considered a qualitative intervention that is extremely effectual for achieving self-awareness.

\section{CONCLUSION}

In a treatment like Faradarmani $^{12}$, the individual becomes

\footnotetext{
${ }^{12}$ Faradarmani is a type of complementary and alternative therapy that is totally Erfan-based in essence, and is considered as a subdivision of Halqeh Mysticism (Erfan-e Halqeh). This doctrine with a 30-year history is based on
} 
pragmatically familiar with Divine Consciousness or Interuniversal Consciousness ${ }^{13}$ (the divine agent in performing this treatment), and this experience itself is a turning-point that moves him towards the source of this consciousness that is God. Thus, such a treatment can mark the beginning of mysticism. Further, through Faradarmani, the Fara-therapist himself accomplishes considerable mystical transformation.

\section{REFERENCES}

[1] M. A Taheri, Human from Another Outlook, 9th Edition, Iran: Bijan publication, 2010, ch. 2, pp. 56-70.

[2] M. A. Taheri, Human and Insight, Armenia: Grigour Natoyasi, 2011, ch. 2, pp. 152-153.

[3] M. A. Taheri, A Collection of Articles, Armenia: Grigour Natoyasi, 2011, ch. 16165 , pp. 37.

[4] M. A. Taheri, "Definition of transcendent individual, and his aging as approached by Halqeh Mysticism," in Procedia Social and Behavioral Sciences, to be published

[5] M. A. Taheri, Human Worldview, Iran: Tohfeh Publication, 2010, ch. 1, pp. 12.

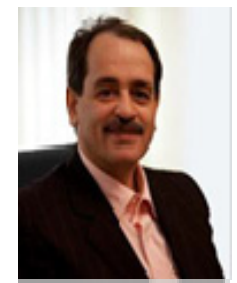

Mohammad Ali Taheri is the founder of Halqeh mysticism (Erfan-e Halqeh) or Interuniversal mysticism, and the two Iranian complementary and alternative medicines of Faradarmani and Psymentology. He holds a BS degree in Mechanics (Turkey). After three years of research on these two C.A.M medicines, the university of traditional medicine of Armenia conferred an honorary doctorate degree in the field of complementary medicine to him (2010). The International Eco-energy Academy of the Republic of Azerbaijan also conferred upon him two honorary $\mathrm{PhD}$ degrees in complementary and alternative medicine and mysticism in two consecutive years (2009 and 2010, respectively).

Dr. Mohammad Ali Taheri has introduced Faradarmani and Psymentology and their education by publishing books and articles, attending international conference, holding educational classes, and training instructors in this science for the past two decades. Eight books and numerous articles have been published by him, and more books are being prepared for publishing (it is estimated to reach around 130 titles). The published books include: Halqeh mysticism (Iran, Andisheye Mandegar, 2009), Human from another Outlook (Iran, Bijan, 2010), Human Worldview (Iran, Tohferh, 2011), Non-organic Viruses (Armenia: Grigour Natoyasi, 2011), Human and insight (Armenia: Grigour Natoyasi, 2011), and A Collection of Articles (Armenia: Grigour Natoyasi, 2011). perceptual revelations [stemming from direct insights]. It was founded by the current author, Mohammad Ali Taheri. (For details please refer to "Human from another outlook," by M.A. Taheri)

${ }^{13}$ Interuniversal Consciousness of Interuniversal (cosmic) internet is the collection of consciousness, awareness, or the intelligence governing the universe. (For details please refer to "Human from another outlook," by M.A. Taheri) 